On a Series of Skulls, Collected by John E. Pritchard, Esq., F.S.A., from a Carmelite Burying-Ground in Bristol

Author(s): John Beddoe

Source: The Journal of the Royal Anthropological Institute of Great Britain and Ireland, Vol. 37 (Jul. - Dec., 1907), pp. 215-219

Published by: Royal Anthropological Institute of Great Britain and Ireland

Stable URL: http://www.jstor.org/stable/2843315

Accessed: 06-01-2016 15:19 UTC

Your use of the JSTOR archive indicates your acceptance of the Terms \& Conditions of Use, available at http://www.jstor.org/page/ info/about/policies/terms.jsp

JSTOR is a not-for-profit service that helps scholars, researchers, and students discover, use, and build upon a wide range of content in a trusted digital archive. We use information technology and tools to increase productivity and facilitate new forms of scholarship. For more information about JSTOR, please contact support@jstor.org.

Wiley and Royal Anthropological Institute of Great Britain and Ireland are collaborating with JSTOR to digitize, preserve and extend access to The Journal of the Royal Anthropological Institute of Great Britain and Ireland. 


\title{
ON A SERIES OF SKULLS, COLLECTED BY JOHN E. PRITCHARD, ESQ., F.S.A., FROM A CARMELITE BURYING-GROUND IN BRISTOL.
}

\author{
BY John BedDoe, M.D., LL.D., F.R.S.
}

\section{[With Plate XXII.]}

IT is my object in the following paper to give a fuller description than has yet appeared of this very interesting find, from the anthropological point of view. Everything else that can be said about it has been well said already by Mr. John E. Pritchard, in his paper in the Transactions of the British and Gloucestershire Archoeological Society, to which I contributed a brief report on the bones discovered. I will only premise now that this Carmelite Friary was founded about 1270, probably by Prince Edward, afterwards King Edward I.; that it endured till the dissolution by Henry VIII. ; that there was a fine church, in which it is stated some eminent citizens were buried; but that the bony remains hereinafter described were not found in any vaults or buildings, but in the open ground, though buildings of later date had covered most of the site. These buildings were hastily removed, and the site quickly excavated for the reception of a new one, under the provisions of a contract which necessitated haste; but the foresight of Mr. Pritchard, and the goodwill of the contractor Mr. Hayes, and of the clerk of the works, Mr. Ashley, secured eleven skulls in more or less measurable condition, under somewhat difficult circumstances. The soil was a strong red marl, and the bodies lay at no great depth in it, often one above another, in two or even three strata. They were all masculine: there were no women or children. There was not a vestige of a coffin, nor of anything in the way of clothing, with the exception of one buckle, which has been figured by Mr. Pritchard.

The greater part of the crania that were found in anything like good condition were preserved, owing to the zeal and care of the gentlemen superintending the work. The facial bones generally, and the mandibles in several cases, were saved, though some of the latter could not be allocated with certainty. Some of the principal measurements have been published in the appendix to Mr. Pritchard's paper; but the whole of those taken on the crania, with the individual descriptions, are here presented to the Institute, and by the great kindness of Mr. Pritchard I am enabled to give, in illustration, some excellent photographs, by Mr. Brightman of Bristol, of four of the most interesting heads. ${ }^{1}$

1 The long bones were too much broken up to yield any valuạble evidençe as to stature.

VoL. XXXVII. 
Journal of the Royal Anthropological Institute, Vol. XXXVII, 1907, Plate XXII.

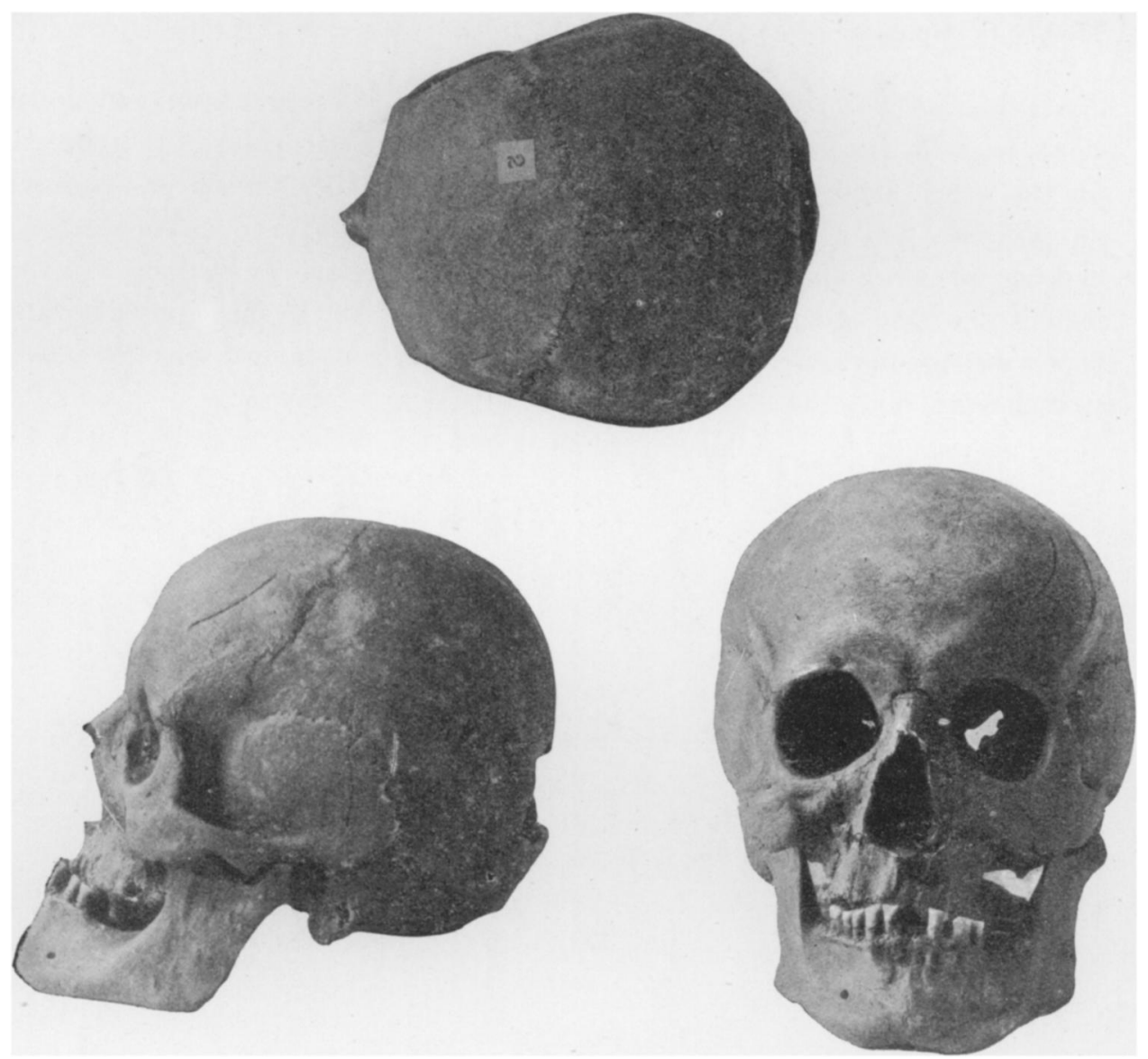

SKULL No. 2 .

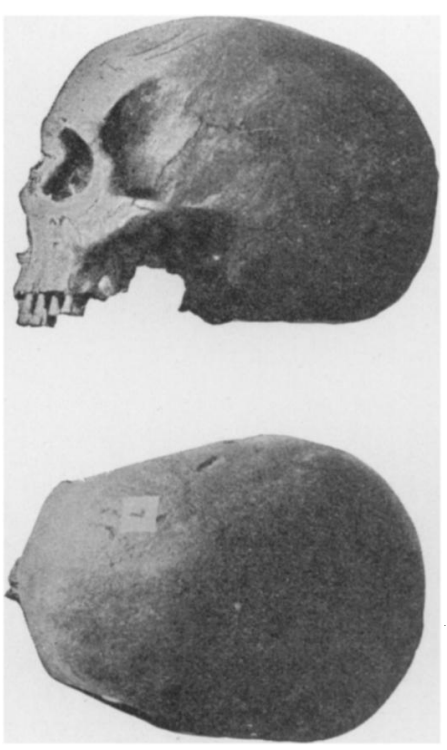

SKULL No. 7.
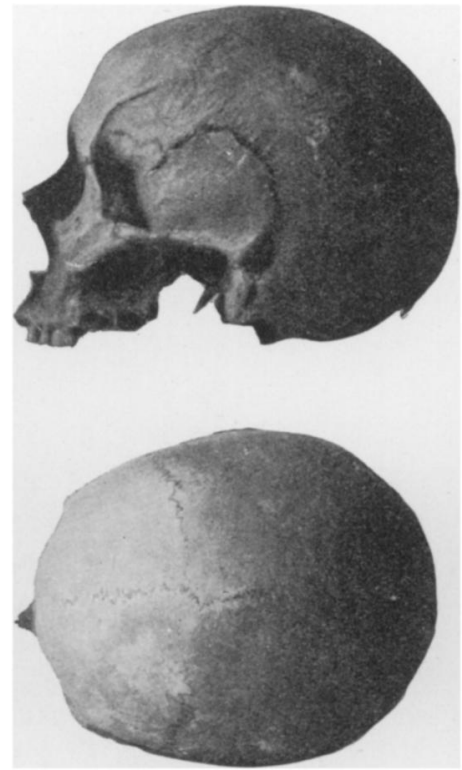

SKULL No. 4.

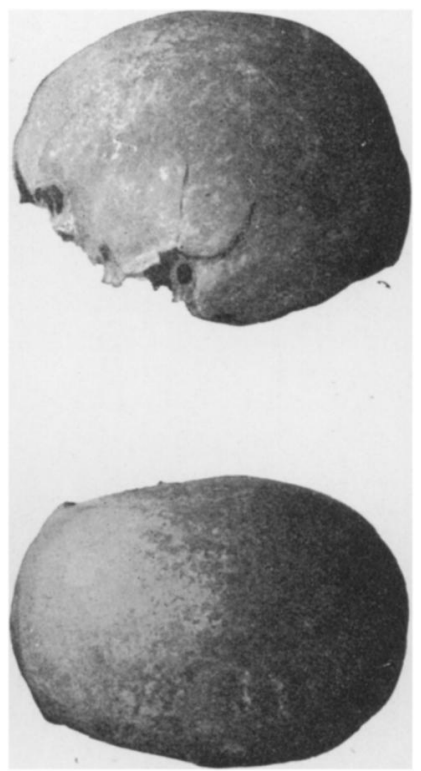

SKULL No. 3. SKULLS FROM A CARMELITE BURYING GROUND, BRISTOL. 
Large "finds" of mediæval skulls are uncommon, and when they do occur, the opportunity of utilising them for scientific purposes is generally lost, from haste, or negligence, or quasi-religious prejudice. The great Whitechapel and Moorfields finds, which Professors Thane and Pearson and Dr. Macdonell have utilised so thoroughly, are brilliant exceptions. One which might have proved equally valuable, at Bradford in Yorkshire, lately slipped through the hands of Dr. Rowe and myself, to our great mortification. The present one, though comparatively small, seems to me of considerable value, partly from the clear identification of its origin, but chiefly from the conspicuous manner in which the skulls fall into two extremely dissimilar groups. This is clearly exhibited in one of the annexed tables, as well as in the following arrangement of the eleven indices :-

$$
72,73,74,75,76,77,78,79,80,81,82,83,84 \text {, }
$$

$\begin{array}{lllllllll}1 & 1 & 1 & 1 & 1 & 1 & 1 & 2 & 2\end{array}$

Here all the five brachycephals are of large capacity, some very large; all are lofty (over 74) with good frontal and general development; while the three dolichos are small in capacity, low in elevation, narrow in forehead. The three which are intermediate in cranial index are all more or less imperfect: two at least of them are of good capacity; but they are of ordinary English or AngloSaxon type, and do not at all resemble the brachycephals, but may be classified, if at all, with Nos. 3 and 9, though they differ therefrom by greater breadth.

Before attempting to explain the remarkable discrepancies mentioned above and set forth in detail in the table, I must refer my reader to a paper in the Journal for 1899, to one "Sur l'histoire de l'Index Céphalique dans les Îles Britanniques" in l'Anthropologie, and to the measurements from the St. Werburgh's find, tabulated in my Races of Britain. Therein will be found my reasons, based partly on craniological evidence, partly on history and on the surnames, for thinking that the mediæval population of Bristol was largely mixed with French blood, and that more from the brachycephals of Gascony than from the less broad-headed Normans. In the present case, however, it would rather seem as though we had to do with two distinct elements of population of strongly contrasted types, rather than, as appeared to be the case under the vaults of St. Werburgh's, with a type formed by the almost complete fusion of two elements. I am thus led to form another conjecture, which I have already put forward in the appendix to Mr. Pritchard's paper in the Bristol and Gloucestershire Transactions, viz.: that the broad, full-brained heads may have belonged to friars, but the small and narrow ones to some of the plebeian lay brethren. These latter would naturally enough be of English or rather native extraction: they may have been not citizens by birth, but immigrants from the less de-Anglicised rural neighbourhood. The first occupants of the Friary may very likely have been brought by the founder from Gascony or even Burgundy, and brought their broad heads with them; and by some not inconceivable chance we may have got hold of the remains of them. In 
those days community of creed and of clerical profession was often a stronger bond than that of country or race. The commerce and other intercourse between Bristol and Aquitaine must have continued active until the loss of Bordeaux about the middle of the fifteenth century. And later burials may have been, not in the open ground, but in the crypt or vaults, as I suppose those of the eminent citizens above mentioned must have been.

Including those under consideration, I now possess the measurements of forty-nine male crania of the mediæval period, found in Bristol: 'forty-six of these I have myself examined and measured. Their average dimensions were 186.6 (length); 146.6 (breadth); and, in thirty-eight, 133.15 (basibregmatic height) giving indices of 78.58 and $71 \cdot 4$.

The number is considerable, and one is tempted to contrast these proportions with those of the Bristolians of to-day and yesterday. Ten modern, but not recent, male skulls from St. Werburgh's graveyard gave 78.1 and $71 \cdot 2$, but seven females of the same origin only $74 \cdot 2$ and $71 \cdot 7$, showing a somewhat greater tendency to dolichocephaly. And eighty contemporary (living and male) Bristolians gave me an index of only $77 \cdot 65$, precisely the same as I got from 170 Somerset and Gloucestershire men. On the usual theory of the two degrees of difference between the living head and the dead skull, this would imply a cranial index of about 75.65 or, say, nearly 76 , which approaches the confines of dolichocephaly. But even if we make no allowance at all for the difference under. discussion, we find the modern head distinctly narrower than the mediæval one. Yet the seventeenth century London head (probably the low-class head, while our figures relate partly at least to the higher class) was of still narrower proportions, 75.1 or 75.4 . Clearly, if we wish to have any very positive knowledge as to the mediæval English head, we must be on the alert to secure further material, and if possible, as Dr. Macdonell remarks, from a rural district. Meanwhile I must yet once more call attention to the fact that a large proportion of my mediæval material belonged presumably to ecclesiastics and not impossibly to foreigners, who may have unduly raised the index of breadth. I may also remark that No. 7 of my Carmelite skulls departs considerably from the common Anglo-Saxon, Frisian or indeed English types, and that I think I see in it some approach to the one which Macdonell finds so frequent among his Moorfields and Whitechapel collections, and which he is disposed to liken to the long-barrow type. In my own opinion its chief measurements are not nearer to those of the ordinary long-barrow man than to those of the Rowgrave man, for example: probably it might crop up in the course of urbanisation in any race of European dolichocephals; but it does seem to occur in Sicily; and it is not common among the old Anglo-Saxons or the modern English. After all, one must confess that a trained eye can tell us more, sometimes, than the most elaborate craniometer; but the trained eye grows dim and perishes, and its impressions vanish, while the printed results of craniometry may go for ever, or till craniometry loses all interest and value.

Many of us think that the comparatively sluggish brachycephal is destined, 
218 JoHn BEDDOE.-On a Series of Skulls from a Carmelite Burying Ground, etc.

like a phagocyte, to envelop and exterminate the restless and migratory dolichoblond, in civilised countries. There are plenty of facts that point in that direction. On the other hand, Pittard's observations seem to indicate a converse process in the Wallis; and the same is said to be the case in Tyrol. Ammon and De Lapouge seem to find a dark long-headed type to be the growing one. I think such is the case among the proletariat in England; but I cannot prove it: and I have a strong impression as to the important part which conjugal selection bears in such changes. 


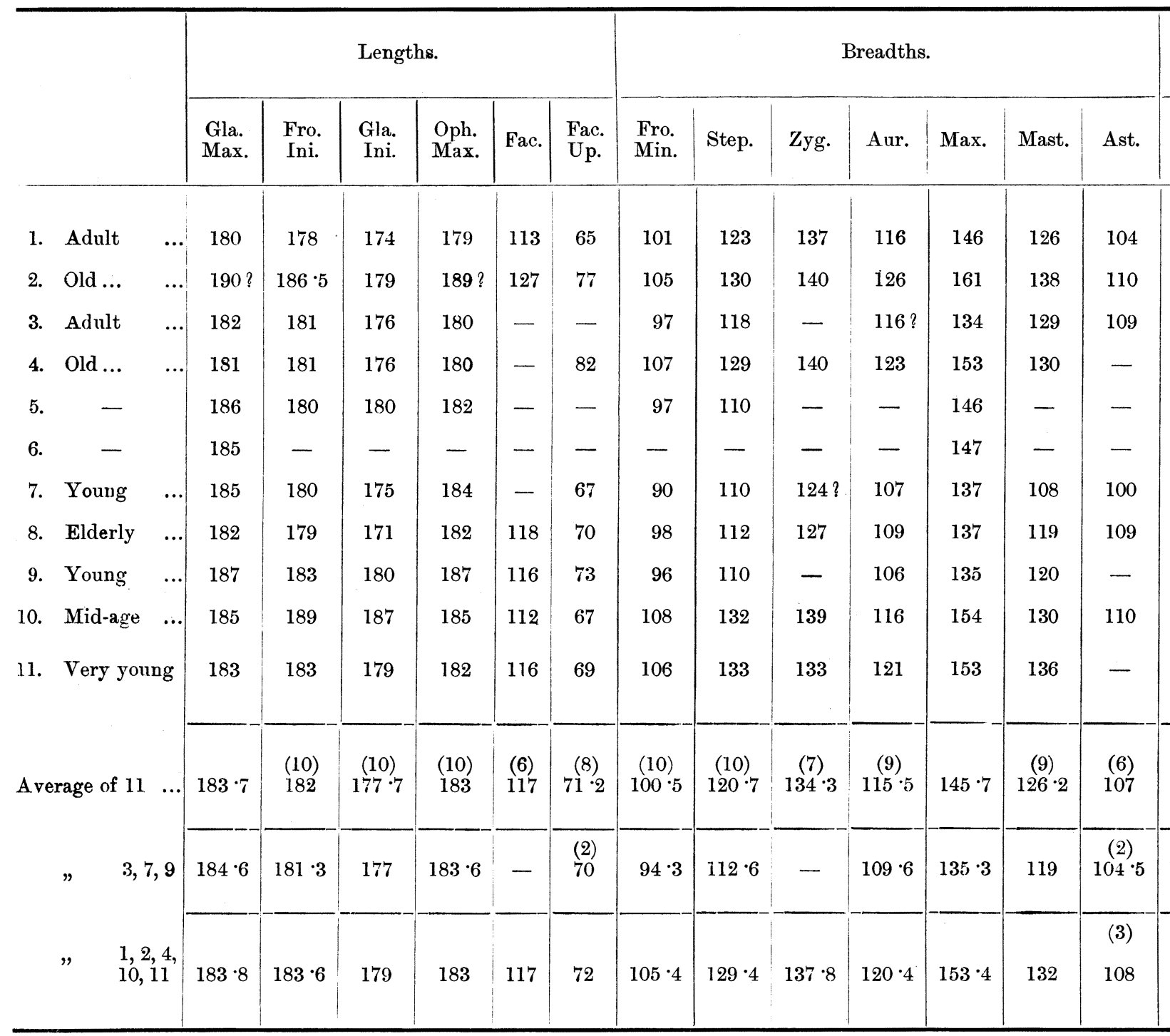

* The height,

The measures are those I usually take : they mostly explain themselves. The transverse arc (Q) and the anterior arc are taken from the centre of the auditory meatus, in the manner of. Von Baer and Busk: the former crosses the bregma. The "auricular" breadth at the pit above the root of the zygoma. The circumference as low down on the glabella as conveniently may be. Facial heights from Nasion.

1. Regular broad oval; maxillary breadth not far back, glabella moderate, orbits squarish, teeth sound, slightly prognathous, nose aquiline.

2. Occiput broken in, decayed from resting on damp earth, had perhaps been bothrocephalic. Sphenoid in vertical, cuboid in lateral aspect, maximum breadth posterior edge of temporals, bregma ossified, orbits rounded, fine domed forehead, opisthognathous, teeth sound, but worn smooth, nose fine, thin, high. Magniticent skull ; resemblance to the late Dean Elliot.
3. Regular which is acumin

4. Regular somewhat penta Resembles No. 2

5. Ovo-pyr

6. Full reg of "firmness," A

7. Beloid o unworn ; wisdon

8. Ovo-elli fine, thin, promi 
Breadths.

Height.

Arcs.

\begin{tabular}{|c|c|c|c|c|c|c|c|c|c|c|c|c|c|c|c|}
\hline Aur. & Max. & Mast. & Ast. & $\begin{array}{l}\text { Bas. } \\
\text { Breg. }\end{array}$ & $\begin{array}{l}\text { Bas. } \\
\text { Max. }\end{array}$ & Circ. & Fro. & Par. & $\begin{array}{l}\text { Oc. } \\
\text { Up. }\end{array}$ & $\begin{array}{l}\text { Oc. } \\
\text { Lo. }\end{array}$ & $\begin{array}{l}\text { Sagit. } \\
\text { 'Tot. }\end{array}$ & $\begin{array}{l}\text { For- } \\
\text { amen. }\end{array}$ & $\begin{array}{l}\text { Bas. } \\
\text { Na. }\end{array}$ & $\begin{array}{l}\text { Bas. } \\
\text { Alv. }\end{array}$ & $\begin{array}{l}\text { Tra. } \\
\text { (Q.) }\end{array}$ \\
\hline 116 & 146 & 126 & 104 & 135 & - & 530 & 122 & 133 & 70 & 41 & 366 & 36 & 101 & 99 & 333 \\
\hline 126 & 161 & 138 & 110 & 148 & - & 560 & 136 & 20 & & 52 & 392 & 38 & 103 & $91 ?$ & 359 \\
\hline $116 ?$ & 134 & 129 & 109 & 131 & $132 \cdot 5$ & 519 & 130 & 125 & 55 & 63 & 373 & 39 & 95 ? & - & 317 \\
\hline 123 & 153 & 130 & - & 135 & 135 & 540 & 132 & 128 & 76 & 47 & 383 & 37 & 97 & 98 & 350 \\
\hline- & 146 & - & - & - & - & $534 ?$ & 135 & 125 & 77 & 51 & 388 & - & - & - & - \\
\hline- & 147 & - & - & - & - & - & 135 & 127 & 78 & 44 & 384 & - & - & - & - \\
\hline 107 & 137 & 108 & 100 & 126 & - & 517 & 132 & 130 & 75 & 46 & 383 & 35 & 102 & 102 & 310 \\
\hline 109 & 137 & 119 & 109 & - & - & 516 & 130 & 124 & 71 & 48 & 373 & 33 & 97 & 96 & 322 ? \\
\hline 106 & $13 \tilde{~}$ & 120 & - & 132 & - & 521 & 129 & 131 & 71 & 52 & 383 & 36 & 98 & 94 & 308 \\
\hline 116 & 154 & 130 & 110 & 143 & - & 533 & 136 & 134 & 58 & 54 & 382 & 34 & 109 & 101 & 348 \\
\hline 121 & 153 & 136 & - & $137^{*}$ & - & 535 & 132 & & & 44 & 382 & - & - & - & 340 \\
\hline $\begin{array}{c}(9) \\
115^{\circ} 5\end{array}$ & $145 \cdot 7$ & $\begin{array}{c}(9) \\
126 \cdot 2\end{array}$ & $\begin{array}{c}(6) \\
107\end{array}$ & $\begin{array}{c}(8) \\
136\end{array}$ & - & $\begin{array}{c}(10) \\
531 \cdot 5\end{array}$ & $131 \cdot 8$ & $\begin{array}{c}(9) \\
128^{\circ} 5\end{array}$ & $\begin{array}{c}(9) \\
71 \cdot 2\end{array}$ & $49 \cdot 9$ & $380 \cdot 8$ & $\begin{array}{l}(8) \\
36\end{array}$ & $\begin{array}{c}(8) \\
100 \cdot 2\end{array}$ & $\begin{array}{c}(7) \\
95 \cdot 8\end{array}$ & $\begin{array}{c}(8) \\
329 \cdot 8\end{array}$ \\
\hline $109 \cdot 6$ & $135 \cdot 3$ & 119 & $\begin{array}{c}(2) \\
104 \cdot 5\end{array}$ & $129 \cdot 0$ & - & 519 & $130 \cdot 3$ & $128 \cdot 6$ & 67 & $53 \cdot 6$ & $379 \cdot 6$ & $36 \cdot 6$ & 99 & $\begin{array}{l}(2) \\
98\end{array}$ & $311 \cdot 6$ \\
\hline & & & (3) & & & & & (3) & (3) & & & (4) & (4) & (4) & (4) \\
\hline $120 \cdot 4$ & $153 \cdot 4$ & 132 & 108 & $139 \cdot 6$ & - & $539 \cdot 6$ & $1311^{\circ}$ & $131 \cdot 6$ & 68 & $47 \cdot 6$ & 381 & $36 \cdot 2$ & $102 \cdot 5$ & $97 \cdot 2$ & $345 \cdot 5$ \\
\hline
\end{tabular}

* The height, 137, is conjectural ; that from opisthion to $1 \frac{1}{2}$ inch behind bregma is 146 .

cansverse e manner th at the abella as te, orbits aps been posterior gnathous, ice to the
3. Regular smooth ellipse ; domed forehead ; inion huge, forms extreme point of occiput, which is acuminate.

4. Regular broad oval ; maximum breadth temporal, forehead domed ; norma occipitalis somewhat pentagonal ; orbits squarish; three teeth sound, worn ; nose fine, thin, high, Resembles No. 2 .

5. Ovo-pyriform : superior curve regular, one temporal missing.

6. Full regular oval, occiput rounded, well filled, superior outline convex in region of "firmness," Anglo-Saxon type.

7. Beloid or sphenoid, lateral aspect oblong, nose doubtful, forehead domed, teeth good, unworn ; wisdom teeth coming through.

8. Ovo-elliptic ; cerebellar region full, flat floored; forehead domed, brows flat, nose fine, thin, prominent; teeth sound, worn.
9. $\mathrm{C}$ over " fir phænozys 10. receptacu aquiline $o$ 11. flat, some occipito-p not throus 


\begin{tabular}{|c|c|c|c|c|c|c|c|c|c|c|c|c|c|c|c|}
\hline \multirow[b]{2}{*}{$\begin{array}{l}\text { For- } \\
\text { amen. }\end{array}$} & \multirow[b]{2}{*}{$\begin{array}{l}\text { Bas. } \\
\text { Na. }\end{array}$} & \multirow[b]{2}{*}{$\begin{array}{l}\text { Bas. } \\
\text { Alv. }\end{array}$} & \multirow[b]{2}{*}{$\begin{array}{l}\text { Tra. } \\
\text { (Q.) }\end{array}$} & \multirow[b]{2}{*}{ Ant. } & \multicolumn{2}{|c|}{ Orbit. } & \multicolumn{2}{|c|}{ Nose. } & \multicolumn{4}{|c|}{ Mandible. } & \multicolumn{2}{|c|}{ Indices. } & \multirow{2}{*}{ 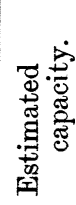 } \\
\hline & & & & & B. & H. & L. & B. & Chin. & Body. & Ram. & Big. & Lat. & Alt. & \\
\hline 36 & 101 & 99 & 333 & 294 & 37 & $33 \cdot 5$ & 44 & 25 & 34 & 95 & 71 & - & $81 \cdot 66$ & 75 & 1526 \\
\hline 38 & 103 & $91 ?$ & 359 & - & $38 \cdot 5$ & $33 \cdot 5$ & 58 & 26 & 41 & 98 & 71 & - & $84 \cdot 74$ & $77 \cdot 9$ & 1859 \\
\hline 39 & $95 ?$ & - & 317 & 278 & - & - & - & - & - & - & - & - & $73 \cdot 62$ & 72 & 1381 \\
\hline 37 & 97 & 98 & 350 & 295 & 38 & $35 \cdot 5$ & 56 & 24 & - & - & - & - & $84 \cdot 53$ & $74 \cdot 6$ & 1608 \\
\hline - & - & - & - & - & - & - & - & - & - & - & - & - & $78 \cdot 5$ & - & - \\
\hline - & - & - & - & - & - & - & - & - & - & - & - & - & $79 \cdot 4$ & - & - \\
\hline 35 & 102 & 102 & 310 & $270 ?$ & 36 & 33 & 45 & 21 & - & - & - & - & $74^{\circ} 0$ & $68 \cdot 1$ & 1390 \\
\hline 33 & 97 & 96 & $322 ?$ & - & 36 & 32 & 51 & 23 & 32 & - & - & - & $75 \cdot 27$ & 72 & 1451 \\
\hline 36 & 98 & 94 & 308 & 278 & 40 & $34 \cdot 5$ & 51 & 25 & - & 82 & - & 94 & $72 \cdot 2$ & $70 \cdot 6$ & 1422 \\
\hline 34 & 109 & 101 & 348 & - & 38 & 27 & 48 & 25 & 33 & 89 & 62 & $94 ?$ & $83 \cdot 24$ & $77 \cdot 3$ & 1688 \\
\hline - & - & - & 340 & 289 & $\left\{\begin{array}{l}38 \\
36\end{array}\right.$ & $\left.\begin{array}{l}36 \\
36\end{array}\right\}$ & 49 & 21 & 33 & 83 & $?$ & 97 & $83 \cdot 6$ & $74 \cdot 83$ & 1655 \\
\hline $\begin{array}{l}(8) \\
36\end{array}$ & $\begin{array}{c}(8) \\
100 \cdot 2\end{array}$ & $\begin{array}{c}(7) \\
95 \cdot 8\end{array}$ & $\begin{array}{c}(8) \\
329 \cdot 8\end{array}$ & $\begin{array}{r}(6) \\
283\end{array}$ & $\begin{array}{c}(8) \\
37 \cdot 5\end{array}$ & $\begin{array}{c}(8) \\
33 \cdot 4\end{array}$ & $\begin{array}{c}(8) \\
50 \cdot 2\end{array}$ & $\begin{array}{c}(8) \\
24 \cdot 7\end{array}$ & $\begin{array}{c}(5) \\
34^{\circ} 6\end{array}$ & $\begin{array}{c}(5) \\
89 \cdot 4\end{array}$ & - & - & $79 \cdot 16$ & $\begin{array}{c}(8) \\
73 \cdot 4\end{array}$ & $\begin{array}{c}(8) \\
1565\end{array}$ \\
\hline $36 \cdot 6$ & 99 & $\begin{array}{l}(2) \\
98\end{array}$ & $3111^{\circ}$ & $275 \cdot 3$ & $\begin{array}{l}(2) \\
38\end{array}$ & $\begin{array}{c}(2) \\
33 \cdot 7\end{array}$ & $\begin{array}{l}(2) \\
48\end{array}$ & $\begin{array}{l}(2) \\
23\end{array}$ & - & - & - & - & $73 \cdot 3$ & $70 \cdot 2$ & 1398 \\
\hline (4) & (4) & (4) & (4) & (3) & & & & & (4) & (4) & & & & & \\
\hline $36 \cdot 2$ & $102 \cdot 5$ & $97 \cdot 2$ & $345 \cdot 5$ & $292 \cdot 6$ & $37 \cdot 7$ & $33 \cdot 5$ & 51 & $24 \cdot 2$ & $35 \cdot 2$ & $96 \cdot 2$ & - & - & $83 \cdot 55$ & $75 \cdot 9$ & 1666 \\
\hline
\end{tabular}

regma is 146 .

point of occiput, orma occipitalis ine, thin, high.

nvex in region aed, teeth good, orows flat, nose
9. Oval, slightly pentagonal, but forehead arched in norma verticalis ; 324 transversely over "firmness"; laterally has A.S. aspect, brows not marked, orbits small, rounded; phænozygous, frontal suture, maxillary prognathism, slight bothrocephalism.

10. Broad ellipse ; regular curve in profile; bigh domed forehead, occiput rounded, receptaculum cerebelli small, flat, foramen far back, inion large, orbits oblong, nose short, aquiline or prominent ; 20 teeth, sound, worn.

11. Ovo-elliptic, but in norma lateralis quadrate, forehead vertical, domed, glabella flat, some alveolar prognathism, nasal form doubtful, orbits megaseme, circular. Right occipito-parietal region much decayed, probably from disease; very young, wisdom teeth not through. 
JoHn BEDDOE.-On a Series of Skulls from a Carmelite Burying Ground, ete. 219

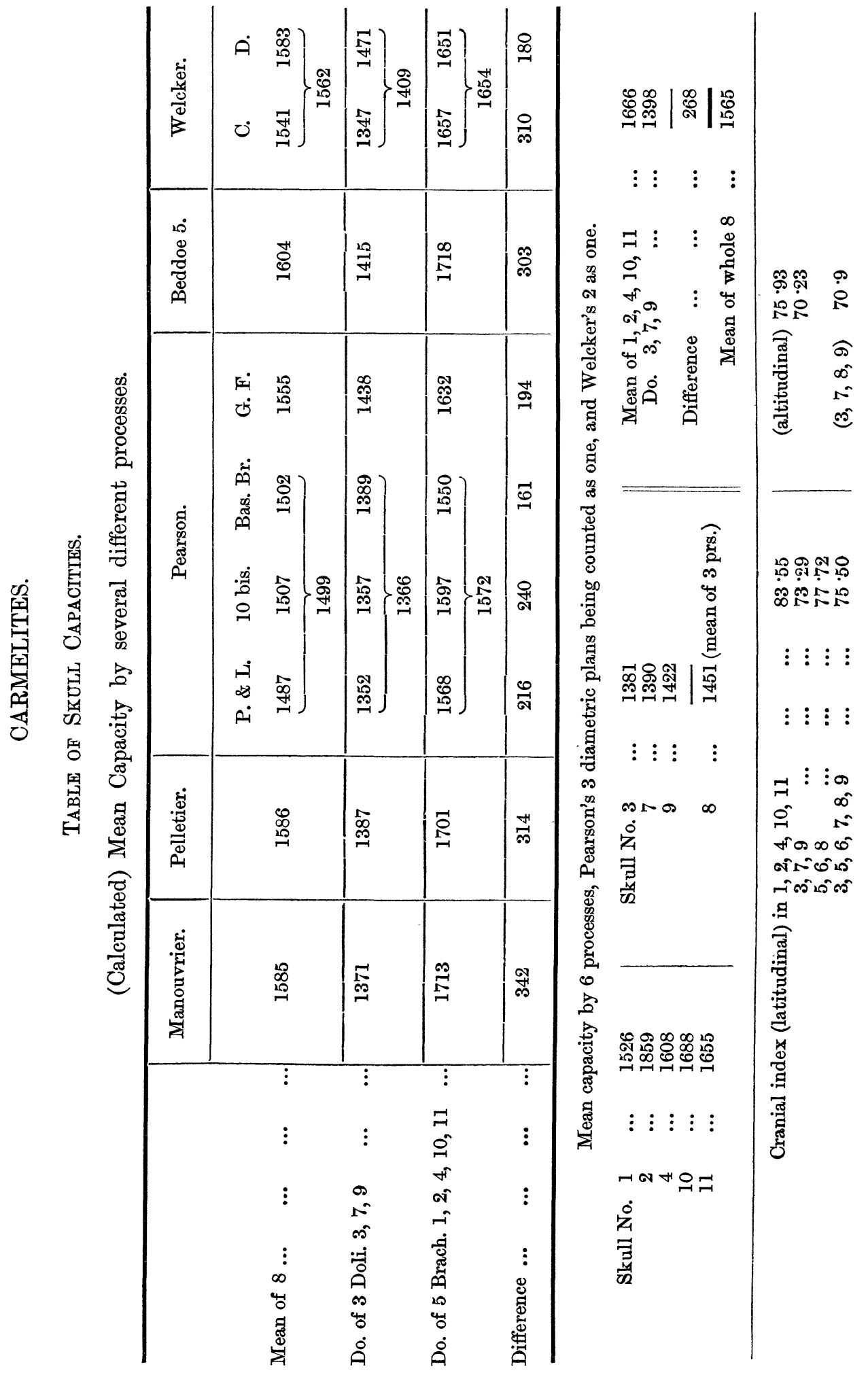

